\section{Calendar of Nature Topics}

Ice off Newfoundland

March 20.--During the winter the sea is firmly frozen in Baffin Bay and among the islands of the Arctic Archipelago, and numerous icebergs calved from the glaciers of Greenland are frozen in. Early in spring these ice masses break up and drift into Davis Strait, where they are carried rapidly southeastwards by the Labrador Current, drifting parallel with the coast of Labrador, and entering the Atlantic off Newfoundland. Here the thin ice-floes quickly disintegrate in the warm water, but the icebergs have a longer life, drifting in the eddying currents off Newfoundland and sometimes penetrating far into the Atlantic, where they constitute a grave danger to shipping. On April 14, 1912, the s.s. Titanic struck a berg in long. $41^{\circ} 46^{\prime} \mathrm{N}$., lat. $50^{\circ} 14^{\prime} \mathrm{W}$., and sank with great loss of life. Both the amount of ice and date of arrival vary greatly from year to year, but March 20 is about an average date for the bergs to appear in quantity over the Newfoundland Banks.

\section{The Spring Equinox}

March 21.-Although in the meteorological calendar spring begins on March 1 , it is often nearer the close of the month before the earth begins to awake under the influence of rising temperature and increasing power of the sun's rays. 'The surface of the soil first responds to the greater insolation, and an apt saying relates that on St. Patrick's Day (March 17) "the warm side of a stone turns up", signifying that about this time heat begins to flow downwards into the ground from above instead of the ground giving up heat to the air.

\section{Spring Winds and some Biological Effects}

There is no doubt that wind, especially at certain seasons, is a factor of considerable ecological importance. South-westerly winds cause a drift of the zooplankton towards the eastern shore of the Southern Bight in spring, and herring coming in through the Straits of Dover naturally veer towards their food. The spring maximum, however, of the colonial flagellate Phoeocystis occurs off the Dutch coast. This organism is disliked by herring. On meeting it in quantity, some of the shoals turn westwards toward English waters (Savage, J. Ecol., 20, 2). Easterly winds on occasion bring the plankton towards the English coast. The herring follow, unless they are repelled by an accompanying drift of Phoeocystis in excessive amount and continue north along the Dutch coast without appearing in the Lowestoft zone.

A succession of strong spring winds in many rivers produces a very heavy mortality among the emerging subimagines of the Ephemeroptera and seriously affects oviposition by the imagines. These insects are a favourite food of various fishes, especially of trout, and excessive losses leading to a reduced stock the following year imply an effect on the faunal balance in several ways.

\section{Elvers Arrive}

For three years the young of the fresh-water eel, in the strange form of leptocephali, have been drifting across the Atlantic Ocean from their distant birth- place, and now in the post-larval elver stage, they begin to enter the rivers of the western coasts of Europe.

In the Severn the fresh-water migration of the elvers begins in March and in such quantities do they appear that they become the objective of a seasonal fishery which lasts until about the middle of May. The elvers generally ascend the river on a high tide, swimming just below the surface of the water, and they are caught by means of hand-nets of cheese-cloth supported upon a large rectangular frame. Although the elver cake referred to by Isaac Walton and other writers is no longer made, the elvers themselves, packed in buckets or barrels, are still sold as food, the dish generally being prepared by washing the elvers in salt and water and afterwards boiling them in fat.

For many years the German Fisheries Union maintained an establishment at Epney on the Severn, from which they exported 3,000,000 living elvers annually for cultivation in German lakes and rivers. In 1920 this station was taken over by the Ministry of Agriculture and Fisheries, which endeavoured to encourage in Great Britain the introduction of eel stock to rivers and lakes otherwise unprofitable.

Since the eel-migration follows the trend of the North Atlantic drift, it is to be expected that the arrival of young eels in the North Sea will be later than on the west coast of Great Britain, so that in east coast rivers the beginning of the elver migration into fresh waters generally takes place in April or more commonly in May.

\section{Barley}

Few of our crops have been studied more than barley. As the raw material for the maltster, its quality takes on great importance, which when reflected in the price, causes farmers to think more about quality than yield. A good malting barley may be worth twice as much per quarter as a coarse sample only fit for feeding. Much work has recently been undertaken to define the illusive idea of quality in scientific terms as distinct from the hand valuation of the market place. The indications are that the good-looking barleys are somewhat favoured and the less attractive rather handicapped by judgment based on external appearance.

of the factors making for quality in barley, soil and season are the most important and are outside the farmers' control. The choice of a suit. able variety of seed is a great help; indeed two varieties alone account for most of the acreage in southern and eastern England, and represent a notable achievement in the production of new strains of cereals. Next comes skilful soil management, and he may count himself fortunate who can so lay his fields that the weather can do most of the work. Finally, there is the matter of manuring, and here the art lies in exploiting the crop-producing powers of fertilisers to the full without running the risk of seriously damaging the quality. It is fortunate that a good yield is not incompatible with a high grade product. It is essential, however, that the manure shall be so measured that the crop can stand up to harvest, and this requires considerable judgment. If the seed can be laid in a good seed bed in the early days of March, the first step towards a useful crop has been taken. The rest depends on the turn of the season. 